\title{
Colliding worlds: Family carers' experiences of balancing work and care in Ireland during the COVID-19 pandemic
}

\author{
Attracta Lafferty $\mathrm{PhD}^{1}$ (D) | Dominique Phillips $\mathrm{MSc}^{1}$ | \\ Linda Dowling-Hetherington EdD ${ }^{1}$ | Majella Fahy PhD ${ }^{1}$ | Breda Moloney MSN ${ }^{1}$ | \\ Clare Duffy MBS ${ }^{2}$ | Gillian Paul PhD ${ }^{1}$ | Gerard Fealy PhD ${ }^{1}$ | Thilo Kroll PhD ${ }^{1}$
}

${ }^{1}$ University College Dublin, Dublin, Ireland

${ }^{2}$ Family Carers Ireland, Dublin, Ireland

\section{Correspondence}

Attracta Lafferty, UCD School of Nursing, Midwifery and Health Systems, Health

Sciences Centre, University College Dublin, Belfield, Dublin 4, Ireland.

Email: attracta.lafferty@ucd.ie

\section{Funding information}

This study was undertaken as part of the larger CAREWELL project (www.carewellpr oject.com), which is funded by the Health Research Board (HRB) Emerging Investigator Awards (EIA) [EIA-2017-039].

\begin{abstract}
The Coronavirus disease 2019 (COVID-19) pandemic public health and social protective measures imposed globally resulted in partial or full closure of key services and supports for services and supports for people with a disability, chronic illness or age-related dependency. This caused huge disruption to care provision and family carers were relied upon to assume this care at home. Many family carers, including those in employment, found themselves navigating additional care responsibilities without 'usual levels' of support from family, friends, work, school, day care services, homecare and community services. The purpose of this study was to examine the impact of the COVID-19 pandemic on family carers, their employment and care-giving responsibilities, through the lens of the Conservation of Resources (COR) theory (Hobfoll, 1989). Adopting a qualitative research approach, 16 family carers (14 females, 2 males) who were in employment prior to the onset of or during the pandemic, participated in an in-depth, semi-structured telephone or online video interview between June and September 2020. Interviews lasted between 45 and 100 min, were audio-recorded and transcribed verbatim. A thematic analysis of the interview data identified four main themes: colliding worlds; navigating unchartered waters alone; opportunity despite adversity and the relentless unknowing. Findings indicate that the onset of the pandemic resulted in the sudden loss of valued resources, which disrupted routines and caused care and work life domains to become intrinsically intertwined. Consistent with the main principles of the COR theory, adapting and transitioning to different ways of working and caring with depleted resources and supports, generated considerable stress for family carers and impacted their wellbeing. The implications for employers, healthcare providers, policy makers and other key stakeholders are considered, to enable family carers to successfully reconcile work with care and protect their well-being, as the pandemic continues to unfold and in the event of future societal crises.
\end{abstract}




\section{KEYWORDS}

Conservation of Resources (COR) theory, COVID-19, employment, family carers, pandemic, qualitative research, workforce

\section{What is known about this topic?}

- Balancing employment with unpaid care can be challenging.

- COVID-19's health and social protective measures meant that working family carers had to provide additional care without the usual formal and informal supports.

- The Conservation of Resources theory has been previously used to understand stress in response to natural disasters and other crises.

\section{What this paper adds?}

- Boundaries between work and care-giving became increasingly blurred during the pandemic presenting new challenges for family carers.

- Consistent with the COR theory, attempting to reconcile work and care with depleted resources generated considerable stress for family carers.

- Recommendations are made for employers and policy makers to protect the employment and well-being of working family carers as the pandemic unfolds.

\section{1 | INTRODUCTION}

The World Health Organization (WHO) declared the novel coronavirus, SARS-CoV-2, causing Coronavirus disease 2019 (COVID-19), a pandemic on March 11, 2020. By November 2020, more than 58 million cases were recorded and more than 1.3 million infected people died globally (Johns Hopkins University of Medicine, 2020). In response to the pandemic, countries around the world implemented a range of protective health and social measures to prevent the transmission of the virus. These included restricted international travel, restricted movement within a specific geographical area, partial or full closure of schools, colleges, childcare facilities, non-essential retail outlets, recreational facilities and businesses. Restrictions were also applied to services, day centres, and other support services that older people, or those with dementia, a disability or a chronic condition frequently avail of, leading to a considerable increase in reliance on families to provide care at home. In addition, there was the imposition of a requirement to work from home, except for those working on the frontline or providing an essential service that could not otherwise be done from home (Health Service Executive (HSE), 2020).

As healthcare systems worldwide became strained treating the surge in infected patients, family carers too became over-stretched and their care-giving role intensified, and often included caring for those deemed high risk of contracting the virus. This included older people and those with compromised immune systems and underlying medical problems such as cardiovascular disease, diabetes, chronic respiratory disease and cancer (World Health Organization, 2020). Many governments recommended that those in this group 'cocooned' (shielded) and remained at home to avoid contracting the virus (Kmietowicz, 2020).

Family carers are considered the backbone of community care provision (Department of Health, 2012). However, many are older carers or have underlying health conditions themselves and were providing increased care at home with limited available supports or services. Respite, day centres, schools and community services were partially or fully closed (Care Alliance Ireland, 2020; Carers UK, 2020a; Family Carers Ireland, 2020) and family carers were conflicted about availing of other 'usual' resources such as help from friends, family members, work colleagues, neighbours or paid home care services because of the imposed restrictions and for fear of infection transmission (Phillips et al., 2020). Recent research has shown that a reduction in formal and informal supports, combined with social distancing measures, has led to higher incidences of stress, anxiety and symptoms of depression among family carers since the pandemic commenced (Cohen et al., 2020; Gallagher \& Wetherell, 2020; Willner et al., 2020).

In Ireland, approximately one in every 10 adults is a family carer (Family Carers Ireland, 2020) and over half are in the paid labour force (Central Statistics Office [CSO], 2016). It is highly likely that the number of people balancing employment with a caring role has increased in Ireland since the onset of the pandemic. According to Carers UK, there is an estimated 2.8 million employees with a new caring role since March of this year (Carers UK, 2020b). Reconciling paid work with care-giving can be challenging for many family carers, however, employment brings many financial, social, health and economic benefits (Calvano, 2013). Work can offer other benefits such as interaction with colleagues, information and access to resources such as Employee Assistance Programmes (Ireson et al., 2018) and is often viewed as a form of 'respite' by family carers, a break from care-giving responsibilities (Joseph \& Joseph, 2019).

The domains of work and care-giving have dramatically changed since the onset of the pandemic. The threat of the pandemic has led to the rapid transformation of working lives with increased 
unemployment rates, abrupt changes to working hours and enforced working from home where possible (CIPD, 2020). Even under 'ideal circumstances', adapting to remote working can be onerous, but doing so while also caring for a sick or dependent relative presents a whole new set of challenges. Working family carers have found themselves having to navigate additional new care challenges, alongside new employment challenges (Phillips et al., 2020). For example, family carers who were essential workers who could not work from home, continued to care for family members at home while being faced with increasingly demanding workloads, all while trying to remain virus-free (Van Houtven et al., 2020). 'Sandwich carers' were also expected to continue to work where possible while providing care to children and ageing parents, with school, childcare and day centre closures and limited community supports. Other working family carers lived in multigenerational households which increased the risk of disease transmission, particularly as restrictions eased and many returned to the workplace (Stokes \& Patterson, 2020).

While a number of theories such as work-family conflict theory (Greenhaus \& Beutell, 1985), carer stress model (Pearlin et al., 1990), role strain theory (Goode, 1960), role conflict theory (Kahn et al., 1964), and spillover theory (Wilensky, 1960) have been postulated to frame stress resulting from multiple demands and roles, the theory of Conservation of Resources (COR) offers an alternative to appraisal-based models of stress (Lazarus \& Folkman, 1984). Instead, the COR theory places a focus on an individual's resources and innate survival response, and views stress as a result of actual, or threatened, loss of resources, such as those lost by family carers in the context of the pandemic. Used previously to understand individuals' responses to natural disasters and the objectively stressful nature of events (Zamani et al., 2006), the theory asserts that 'individuals strive to obtain, retain, protect and foster those things they value' (Hobfoll, 2001, p. 341) and that stress occurs when there is an actual or threatened loss of these valued resources. Burch et al. (2019) examined a range of resources that may be considered helpful for family carers to combine care-giving with paid work. These include resources at the individual level (care-giving self-efficacy, time spent with care-recipient), family/social level (emotional and instrumental support), employer level (flexibility, carer policies, supervisor support) and community level (support groups, respite services).

The COR theory has not previously been applied to working family carers' responses to a crisis situation such as a pandemic, when many valued services and supports have been withdrawn. Therefore, the overall purpose of this study was to explore how the pandemic affected family carers who combined paid employment with a care-giving role, and the findings are presented through the lens of the COR theory.

\section{2 | METHODS}

\section{1 | Research design}

This study was nested in the larger 'CAREWELL' project, which aims to enhance health and self-care among family carers who balance paid work with care responsibilities. As the focus of this study was on exploring the experiences of working family carers during the COVID-19 pandemic, a qualitative research design was adopted (Newell \& Burnard, 2010). This approach allows for rich, in-depth and comprehensive information to be gathered in order to capture the complexity of this unexplored phenomenon (Braun \& Clarke, 2013).

\section{2 | Participants}

Purposive sampling was used to achieve a heterogeneous sample of family carers in terms of sex, age, working status, occupation, relationship to care-recipient, health condition, etc. The inclusion criteria stipulated that participants were over 18 years, cared for a family member(s) due to a disability, chronic illness or age-related dependency and were in employment prior to the onset of or during the pandemic. Family carers were recruited through carer advocacy organisations, social media (i.e. Linkedln, Facebook, and Twitter) and the project team's networks. Interested family carers who were screened and eligible, received a participant information leaflet and consent form and interviews were scheduled for a time and day convenient for the participants, including evenings and weekends.

\section{3 | Data collection}

Sixteen one-to-one, in-depth, semi-structured interviews were carried out with family carers between June and September 2020. In accordance with COVID-19 public health guidelines, interviews were conducted online via video-enabled software $(n=13)$ or by telephone $(n=3)$. With the exception of one interview where the interviewer took notes, all interviews were audio-recorded and transcribed verbatim. Interviews lasted between 45 and $100 \mathrm{~min}$. The interview guide was based on a review of the literature and a guide developed by the research team in consultation with a former working family carer. The guide covered: the impact of the pandemic on family carers, their work and caring roles; changes in informal and formal supports; and challenges or opportunities experienced as a consequence of the pandemic. As interviews were not conducted in-person, the researchers used additional strategies to enhance rapport and trust such as engaging in informal conversation, demonstrating active listening and using statements of appreciation (Drabble et al., 2016). Data collection continued until data saturation was reached (Morse, 2015).

\section{4 | Data analysis}

The interview data was analysed using thematic analysis as it allowed for a combination of inductive and deductive approaches. Initial coding was data-driven and inductively derived from the interview data. Findings were later deductively refined and interpreted in relation to the COR theory. Braun and Clarke's (2006) six-phased framework for 
thematic analysis was used as part of an iterative and reflective process. The first phase 'familiarisation' involved actively reading and re-reading the interview transcripts and recording first thoughts, notes and patterns. The second phase involved 'generation of codes' whereby interview data and participant quotes were organised in a meaningful way through labelling and the initial production of codes using open-coding. Phase three comprised of 'searching for themes' whereby the relationships between preliminary code groupings or clusters were noted and developed. Phase four involved 'reviewing themes' which included re-examining and refining themes in relation to the coded data and the overall dataset and organising them into distinct groups. The fifth phase consisted of 'defining themes' and generating clear definitions for each theme, how they related to each other and the research question and finally these were written up and produced in a report. To enhance reflexivity and rigour, the coding and generated themes were reviewed by all of the interviewers. Transcripts were imported to NVivo v.12 to help with organising the interview data to facilitate analysis.

\subsection{Ethical considerations}

The study received ethical approval from University College Dublin Human Research Ethics Committee (HREC). Participants provided the researchers with written informed consent via email and verbal consent was also given during the recruitment stage and again prior to the commencement of the interview. Process consent was ongoing throughout the interviews. Participants were reminded that their participation was entirely voluntary and they could withdraw at any point. Potential identifiers were removed from the data and pseudonyms were applied. Participants' demographic details were kept purposively vague in order to protect their anonymity. Participants received a debrief sheet following the interview, thanking them, and supplying them with contact details for relevant support organisations.

\section{FINDINGS}

\section{1 | Participant characteristics}

Participants were aged between 30 and 62 years and the majority were female $(n=14)$ (Table 1). Fifteen participants were Irish and one had a dual Irish nationality. Two participants were caring for more than one family member due to a disability, chronic illness or age-related dependency. Twelve participants were employed in the public sector, three in the private sector and one was self-employed. All participants experienced changes in employment arrangements since the commencement of the pandemic. Six participants were considered essential frontline workers.

The following four themes were identified from the data and reflected working family carers' experiences during the COVID-19 pandemic: Colliding worlds; Navigating uncharted waters alone; Opportunity despite adversity; and The relentless unknowing.

TABLE 1 Participant characteristics

\begin{tabular}{|c|c|c|c|c|c|c|c|}
\hline No. & Gender & Age & Provides care for & $\begin{array}{l}\text { Care-recipients' } \\
\text { health condition }\end{array}$ & $\begin{array}{l}\text { Employment } \\
\text { pre-COVID }\end{array}$ & $\begin{array}{l}\text { Employment since } \\
\text { COVID }\end{array}$ & Sector \\
\hline 1 & $\mathrm{~F}$ & 48 & Daughter & Cerebral palsy & Full-time & Working remotely & Public \\
\hline 2 & $\mathrm{~F}$ & 58 & Mother & Lung disease & Full-time & Working remotely & Public \\
\hline 3 & $\mathrm{~F}$ & 52 & Mother & Frailty & Part-time & Working remotely & Public \\
\hline 4 & $\mathrm{~F}$ & 56 & Daughter & Autism \& ID & Part-time & On Carer's Leave & Public \\
\hline $5^{\mathrm{a}}$ & $\mathrm{F}$ & 45 & Son & GDD & Full-time & Increased hours & Public \\
\hline $6^{a}$ & $\mathrm{~F}$ & 50 & Daughter & Down syndrome & Part-time & $\begin{array}{l}\text { Redeployed/increased } \\
\text { hours }\end{array}$ & Public \\
\hline 7 & $\mathrm{~F}$ & 62 & Mother \& father & Dementia, cancer & Part-time & Working remotely & Public \\
\hline 8 & $\mathrm{~F}$ & 56 & Mother & Dementia & Part-time & Redeployed & Private \\
\hline 9 & $M$ & 30 & Wife & Genetic disorder & Part-time & Unemployed & SE \\
\hline $10^{a}$ & $\mathrm{~F}$ & 47 & Daughter & Down syndrome & Part-time & Working remotely & Public \\
\hline $11^{a}$ & $\mathrm{~F}$ & 51 & Father & Cancer & Full-time & Compressed hours & Public \\
\hline 12 & $\mathrm{~F}$ & 36 & Mother & Dementia & Full-time & Working remotely & Private \\
\hline $13^{a}$ & $\mathrm{~F}$ & 46 & Mother & $\begin{array}{l}\text { Bipolar disorder, } \\
\text { frailty }\end{array}$ & Full-time & Working remotely & Public \\
\hline 14 & $\mathrm{~F}$ & $50+$ & Father & Diabetes & Full-time & Working remotely & Public \\
\hline $15^{a}$ & $M$ & 44 & Son & Autism & Full-time & $\begin{array}{l}\text { Some remote work/ } \\
\text { increased hours }\end{array}$ & Public \\
\hline 16 & $\mathrm{~F}$ & 53 & Mother \& husband & Frailty, brain injury & Part-time & Some remote work & Private \\
\hline
\end{tabular}

Abbreviations: GDD, global developmental delay; ID, intellectual disability; SE, self-employed.

${ }^{\mathrm{a}}$ Essential frontline worker. 


\subsection{1 | Colliding worlds}

A theme that was consistently identified throughout the interview data was the sense that two worlds had collided as a result of the pandemic. Participants spoke about the immense time and energy they had invested in developing tailored bespoke routines and systems comprising formal services and informal supports prior to the COVID-19 pandemic, to enable them to successfully reconcile work and caring roles. Suddenly the worlds of work and care collided and participants struggled to acquire new means of negotiating both roles, especially as many family carers began to experience increased workloads. A father described his experience:

Work kind of became completely intertwined with home life and, you know, not going into the office and having a very clear demarcation there and just the extra stress that work threw up, that like on my side, that was the biggest challenge, that it was harder to find time to say right, this is home time now and I can be with Sam and do what he would like to do (C19 15).

The pandemic lockdown restrictions meant that most family carers had to adapt to remote working. As one participant described: 'it was becoming very intense and everyone over-zoomed ... suddenly all these people wanted to have meetings' (C19 14). However, as schools, day centres, childcare and other services began to close down, trialling new ways of working had to be balanced with care-giving responsibilities at home. This was referred to as a 'juggling act' and some carers were getting up at 5 a.m. to be able to accommodate both work demands and care needs. Lunchbreaks were used to make meals for the care-recipient, help them to the bathroom or to administer medication. The following mother of a daughter with cerebral palsy described what working from home was like for her:

I'm working from home as well, so I'm stuck on a laptop or I'm doing Zoom calls or Skype calls, that kind of stuff. Now I'm lucky, she's very, very good in that I had a meeting yesterday on Skype for $2 \mathrm{hr}$ and she sat alongside me with headphones on, but I'm very lucky I could do that. But then it meant that the minute the meeting was over, I had to go and get food for her or I had to change her, you know I had to, you know, get straight back onto the next job, be it my 9-5 job or my caring role (C19 1).

There was also a sense of increased guilt attributed to not being able to fully commit to either work or to a family member's care needs. This internal conflict was particularly true for frontline healthcare workers whose attendance at work became crucial:

The guilt, because I knew she needed me more than she normally did and yet I was less available. That's the guilt you're stuck with! ... There was a pull between 'you're needed in work and you're needed at home'. And feeling [that] no matter where you are, that you're not doing the right thing: if you're at work, you should be at home, if you're at home, you should be at work. It was very hard-going and exhausting (C19 6).

Participants indicated that the incessant interplay of both work and care worlds at home and the blurred boundaries adversely impacted their mental well-being:

They're intertwined and it's hard to get away from either one and that is definitely stressful ... It's relentless ... And I think it's been a huge pressure on mental health, that not having a break (C19 2).

\subsubsection{Navigating uncharted waters alone}

Participants shared their experiences of the sudden closure of essential supports for their care-recipient. Many who had grappled to secure these services prior to the pandemic described how they were suddenly 'all just cut off' (C19 8). One frontline healthcare worker was faced with a situation in which she had no one to care for her children. She spoke about how she would normally rely on friends and family to help out, but during the pandemic, those resources were not available to her, and instead, her husband, also an essential worker was forced to stay at home:

There was 1 week there and we had absolutely no childcare, and I was in the depths of it in work and [name of husband] had to phone in sick you know, to try and get that in order for us to be able to provide for the children (C19 5).

Due to the highly contagious nature of the virus, some family carers were faced with the difficult decision of whether to continue to avail of home care services or halt them to reduce the risk to the care-recipient. One participant explained how she came to the decision:

The carer who comes in the evening time then to get Mam into her pyjamas and her pads and all that for the night, she got tested for the virus and she had it. So that was a very worrying time for the next 14 days to see, you know. So, that was it really, then I decided no, they'll all have to go. So that's where we started then, yeah, from there, so I was doing it all (C19 7).

The extra care load, in addition to adapting to new work arrangements, took its toll on family carers, several of whom spoke about reaching a 'crisis point'. The following participant described how she became overwhelmed: 
I reached a breaking point ... [I was] ringing the public health nurse in floods of tears going 'I can't cope' and she's going, 'do you want respite?', and I was like 'no, she won't go into respite' and then a week later, [l was] going, 'I don't care that she can't cope in respite, I need it, it's not her, it's me' (C19 13).

Similarly, another participant who was adapting to working remotely, while caring for her mother with dementia described how she was affected:

I'm getting upset a lot more in the last month or so about everything and I had a panic attack there during the lockdown and I never had a panic attack in my life you know. I don't know, it's probably a combination of work as well and looking after my mother and the doctor just gave me a week off work and gave me some medication (C19 12).

Without the usual services available, participants frequently felt unsupported, lonely and isolated. Described as 'the forgotten people' (C19 4), some participants explained how service withdrawal together with remote working culminated in feelings of isolation:

Because it's from every aspect of being isolated at home physically, but also being isolated workwise and not seeing people in work even, you know, accomplishing tasks and supporting ... and my own mental health deteriorating during that time so I think isolation has been the worst (C19 13).

The pandemic not only impacted family carers' well-being, but many reported observing a 'decline' in the care-recipient's health, which compounded the situation. Those caring for older parents noted how that they had 'gone downhill' (C19 2; C19 13; C19 14), while one mother spoke about her daughter's frustration at not being able to go to her day centre:

There has been a lot of hitting herself and screaming, and crying and that sort of thing, and this has been happening more and more frequently (C14 4).

\subsection{3 | Opportunity despite adversity}

Despite the fact that family carers became anxious and distressed as care-giving responsibilities and employment were becoming intrinsically intertwined, many still deemed themselves 'lucky' and reflected on the opportunities presented by the pandemic. Several participants acknowledged that remote working helped as they could now 'be around' more for their relative:

Something's going to have to give and ... not that I'm wishing a pandemic on anybody but remote working has resolved [balancing care and work] temporarily, at least in terms of supporting my Mam (C19 3).

The following participant lived some distance from her mother, but as she could now work remotely, she was able to visit and spend time with her. Her mother passed away shortly afterwards, but she was thankful for the time she had with her:

COVID might have been quite dramatic and upsetting around my Mom's healthcare in many ways, on the other hand it was good to be home, I got to see her and that was really good (C19 14).

One participant who became unemployed received the pandemic unemployment payment, which for him, meant that he could enjoy spending time with his new baby:

The financial stress was kind of relieved by getting the financial support and because of that, we were able to enjoy the time at home a wee bit more. In our case it meant enjoying the pregnancy and having the child, so that was a real bonus for us (C19 9).

Spending more time at home brought some families closer together. The following participant was caring for her elderly parents, both of whom had underlying conditions:

I think I have a better relationship with my parents, not that I didn't have before but a closer bond because we've been through this now, through thick and thin like. I like that [as] a positive thing out of this (C19 7).

For other family carers, the pandemic brought a new perspective and a slower pace of life allowing them to have the time needed to reassess priorities:

There's been enough disruption for long enough to actually make me think, what am I doing? Now, I love my job, so if things went back, would I go back? ... I don't know ... So, the positives would be probably being able to disrupt that workaholic treadmill. [That] has probably been positive (C19 2).

\subsection{4 | The relentless unknowing}

The immediate shut down of support services and the unpredictable nature of the pandemic generated a lot of uncertainty among family carers, especially as they were often caring for the most vulnerable. Participants spoke about how 'in normal circumstances', they could draw on support from school, day centre services, grandparents and neighbours, but were unsure when they could do this again. A 
frontline healthcare professional, whose work became increasingly demanding, spoke about the ongoing uncertainty and worry about how she would deal with managing care for her son:

I was kind of constantly fearful and I think that's what contributed to a lot of my stress, was how are we going to manage the next day, what are we going to do? I didn't want to be using annual leave because I didn't know, I was conscious that once school [officially] finished, we were still in the same boat of having no support (C19 5).

When services closed down, the following participant applied for carer's leave (unpaid time off work for carers), so that she could care for her daughter, but she continued to worry about her work situation:

So, I don't know if I'll be able to go back though, you know that way, because [her] service hasn't resumed ... I won't be able to work from home and I don't know what's going to happen, because again I've no certainty that I'll be able to return to work. And I don't know how long they'll let me stay out (C19 4).

There was a sense of fear and vulnerability among participants that the existing services availed of pre-COVID-19, which many family carers had struggled to secure, would resume even after the pandemic. As this participant stated:

When the HSE are short of money, we know we're going to be the very first ones that they go for, you know (C19 4).

Another participant reflected on the future and considered the 'new normal':

You're kind of wondering you know, what's [going to] happen next you know. Am I ever going to get my life back? I suppose, am I ever going to get a break? ... No end to it really, you know, even if things go back to normal, the new normal isn't going to be great for us (C19 1).

\section{4 | DISCUSSION}

This study draws on the COR theory to explain family carers' responses to managing multiple demands and roles during the pandemic. The basic assumption of the theory argues that a loss of resources that people value and struggled to secure, can lead to stress (Hobfoll, 1989). The sudden onset of the pandemic and the imposed restrictions meant that family carers lost many valued resources. Routines were thrown into disarray and the key life domains, work and care-giving, became intrinsically intertwined. Family carers responded by transitioning to different ways of working and caring, with depleted services and supports. While some services responded by offering online services, this approach alone was not considered an adequate substitute (Giebel et al., 2020).

The withdrawal or reduction in services may have long-term negative consequences for family carers. The importance of 'replacement care', which relates to publicly-funded services for carerecipients that enable family carers to remain in the workforce has been highlighted in the literature. Pickard et al. (2018) found that without access to services such as home care, day care centres, meals or respite, there is an increased likelihood that family carers will exit the workforce. Therefore, without this care, it is likely that many family carers are at risk of employment exit as a result of the pandemic. Our findings also revealed that family carers relied significantly on informal sources of support from friends, neighbours, grandparents and other family members, so that they could remain working, however, this was disrupted due to the pandemic. The reliance on this resource, which often goes unnoticed, became increasingly visible during the pandemic, as it became strained due to lockdown restrictions, fear of virus transmission and because those who regularly 'helped out', were older or had underlying health conditions themselves. This level of support required by family carers to enable them to continue to work highlights a huge void in the care system in Ireland and warrants further examination.

As the pandemic unfolded, many family carers grappled with the move to remote working, while attempting to balance increased workloads with increased care loads. Prior to the pandemic crisis, only $14 \%$ of the Irish workforce worked remotely at least 1 day a week (Redmond \& McGuinness, 2020). However, there is no doubt that the pandemic will accelerate flexible work options postCOVID-19. A recent UK survey of 114 employers showed that $75 \%$ of employers offered additional flexible work options for carers during the pandemic, and $61 \%$ offered alternative work arrangements for those caring for a person required to 'cocoon' (Carers UK, 2020c). Employers who had well-established supports for employees with caring responsibilities were better able to provide support and respond to their needs (Carers UK, 2020c). With the incoming European Directive on Work-Life Balance for Parents and Carers (European Parliament, 2019), which came into force on August 1, 2019 , and is due to be transposed into law by member states within 3 years, employees will have the right to request flexible working options in Ireland, a right already available in the UK (Yeandle, 2017).

The very nature of the rapidly evolving pandemic created fear and tension in countries across the globe (Pakpour \& Griffiths, 2020). In our study, adapting to new work demands in the absence of 'usual' supports from family, friends, work, school, homecare and community services (Care Alliance Ireland, 2020; Carers UK, 2020a), exacerbated feelings of isolation and being unsupported, an experience frequently reported by family carers prior to the pandemic (Family Carers Ireland, 2019; Keating \& Eales, 2017). Furthermore, the sense that there was no clear end to the pandemic, generated increased levels of uncertainty and apprehension among family carers, especially as most are caring for a person in the 'high risk' category. The 
isolation, loss of supports together with the challenge of reconciling work and care under unprecedented conditions impacted family carers and many became overwhelmed and reported feelings of distress, anxiety and apprehension. This was further compounded by the observed deterioration in the care-recipients' health and behaviours, and not knowing if services will be fully reinstated postpandemic (Family Carers Ireland, 2020).

The COR theory postulates that prior to a natural disaster, those who already had deficient resources available, have limited reserve capacity to manage stress and have a propensity for negative thoughts and feelings (Hobfoll, 2001). This could be deemed true for family carers who after struggling to secure valued resources for their care-recipient, were feeling vulnerable to further losses. There was a constant fear around whether existing services would be reinstated and whether they could continue in paid employment. The 'not knowing' became relentless for family carers and many struggled to envision how well-established care-work arrangements could continue to be viable in the 'new normal'. Hobfoll (2001) discusses how resource loss can be the best predictor of motivation to cope with the negative impact of natural disasters. He suggests that when individuals experience resource loss, they may engage in denial rather than active coping mechanisms. While the pandemic presented family carers with personal and professional challenges, many fostered adaptive ways of coping and re-evaluated their traumatic experiences (Tamiolaki \& Kalaitzaki, 2020). For example, family carers deemed themselves 'lucky' and identified positive aspects of the pandemic, such as being more available to the care-recipient and being able to work flexibly, which has been highlighted as an important option for working family carers (Lafferty et al., 2020). This could be considered a defensive approach, adopted by family carers in order to reserve resources (Hobfoll, 2001).

\section{1 | Implications}

The study's findings have several implications for policy and practice. The study highlighted the importance of 'replacement care' in enabling family carers to reconcile work with care-giving. Therefore, it is vital that services are fully reinstated when it is safe, and that there is greater access to such services in the future to reduce the number of carers leaving the workforce. Furthermore, as family carers were unable to avail of 'usual' resources and support services, flexibility with their work was pivotal in enabling them to remain working. Therefore employers need to recognise the benefits of offering flexible work options, especially given the increasing number of family carers juggling work and care (Carers UK, 2020b). The study highlighted an increased dependency on family carers, the majority of whom are women. Therefore, it is important that a concerted effort is made by policy makers and employers to ensure that the pandemic does not widen existing employment inequalities (Power, 2020). Health and social care services need to consider innovative ways of supporting family carers remotely, and increase levels of outreach and communication to alleviate anxieties and avoid them becoming isolated and unsupported (Lightfoot \& Moone, 2020). Further research is required to determine the long-term implications of the pandemic on family carers' employment and care-giving supports, and with family carers who are working as part of the gig economy, on precarious contracts and who are self-employed. It is recommended that future longitudinal or cross-sectional research is undertaken to ascertain how the pandemic has impacted different cohorts of carers based on characteristics such as income, employment type, dependency levels of care recipients and levels of social support.

\section{2 | Limitations}

A number of study limitations are noteworthy. Firstly, the majority of family carers were female $(N=14)$, despite CSO figures (CSO, 2016) suggesting that approximately $40 \%$ of family carers in Ireland are male. This could be attributable to a stigma being associated with being a male carer (Maynard et al., 2018). Secondly, the majority of working family carers were middle-aged and held relatively senior work positions (e.g. were managers, supervisors, etc.). Therefore the findings may not provide a true reflection of the experiences of younger, lower-income family carers who may occupy more junior positions and who may have less resources to draw on. Furthermore, with the exception of four family carers, the majority were employed in the public sector. Therefore self-employed family carers or those in the gig economy or private sector may not be adequately represented. A further shortcoming of the study was the lack of demographic diversity among participants. Working family carers have been recognised as a hard to reach cohort (Atanackovic et al., 2020), due to time constraints associated with working and caring, which was likely exasperated by the pandemic and may go some way to explaining the profile of the study participants. Finally, most of the recruitment took place online using social media which means carers without online access may have been unintentionally excluded.

\section{5 | CONCLUSIONS}

Family carers have been the invisible workforce providing frontline care in the community during the COVID-19 pandemic, often without sufficient supports. Findings from this study were consistent with the principles of the COR theory, in which working family carers experienced immense anxiety, uncertainty, isolation and stress due to a loss of resources. This impacted their ability to provide care and perform their work effectively. The findings highlighted the need to increase access to replacement care and that flexible work options are pivotal in enabling family carers to successfully reconcile work and care. The paper provides valuable insights for employers, healthcare providers, policy makers and other key stakeholders and may be useful in informing future services and policies that aim to promote and retain family carers in the workforce and that rely on family carers to provide care in the community. 


\section{ACKNOWLEDGEMENTS}

The authors thank the family carers who gave up their time to participate in this study. Gratitude is also extended to those who supported the recruitment of participants. We are grateful to the Health Research Board (HRB) for funding this research as part of the CAREWELL project.

\section{CONFLICT OF INTEREST}

The authors declared no conflicts of interest.

\section{AUTHOR CONTRIBUTION}

Conception: AL, DP, LDH, MF. Study design: AL, DP, LDH, MF. Participant recruitment $\&$ acquisition of data: AL, DP, LDH, MF, BM, $C D$. Data analysis: AL, DP, LDH, MF, BM. Interpretation of data: AL, DP, LDH, MF, BM, CD, GP, GF, TK. Drafting of manuscript \& revising it critically for important intellectual content: AL, DP, LDH, MF, BM, CD, GP, GF, TK.

\section{DATA AVAILABILITY STATEMENT}

Research data are not shared.

\section{ORCID}

Attracta Lafferty iD https://orcid.org/0000-0003-4042-9592

\section{REFERENCES}

Atanackovic, J., Williams, A., Tompa, E., Ireson, R., \& Yazdani, A. (2020). Overcoming recruitment difficulties in conducting intervention research with carer-employees: Lessons learned from a research study at a Canadian University. Sage. https://doi.org/10.4135/97815 29744897

Braun, V., \& Clarke, V. (2006). Using thematic analysis in psychology. Qualitative Research in Psychology, 3(2), 77-101. https://doi. org/10.1191/1478088706qp063oa

Braun, V., \& Clarke, V. (2013). Successful qualitative research: A practical guide for beginners. Sage.

Burch, K. A., Dugan, A. G., \& Barnes-Farrell, J. L. (2019). Understanding what eldercare means for employees and organizations: A review and recommendations for future research. Work, Aging and Retirement, 5(1), 44-72. https://doi.org/10.1093/workar/way011

Calvano, L. (2013). Tug of war: Caring for our elders while remaining productive at work. Academy of Management Perspectives, 27(3), 204218. https://doi.org/10.5465/amp.2012.0095

Care Alliance Ireland. (2020). Covid-19 and the impact on family carers. Retrieved from https://www.carealliance.ie/userfiles/files/C19_FC_ Research_Overview_V1_Sept2020.pdf

Carers UK. (2020). Caring behind closed doors: Forgotten families in the coronavirus outbreak. Retrieved from https://www.carersuk.org/for-profe ssionals/policy/policy-library/caring-behind-closed-doors-report

Carers UK. (2020). Carers week 2020 research report. Retrieved from https://www.carersuk.org/for-professionals/policy/policy-library/ carers-week-2020-research-report

Carers UK. (2020). Supporting working carers in COVID-19: Response and reflections. Retrieved from https://www.carersuk.org/images/News_ and_campaigns/Supporting_working_carers_in_COVID-19.pdf

Central Statistics Office (CSO). (2016). Profile 9 health, disability and carers. Retrieved from https://www.cso.ie/en/csolatestnews/press pages/2017/census2016profile9-healthdisabilityandcarers/

CIPD. (2020). Impact of COVID-19 on working lives: New findings and anal$y$ sis on the ongoing impact of the coronavirus pandemic on working lives.
Retrieved from https://www.cipd.co.uk/knowledge/work/trends/ goodwork/covid-impact

Cohen, G., Russo, M. J., Campos, J. A., \& Allegri, R. F. (2020). Living with dementia: Increased level of caregiver stress in times of COVID-19. International Psychogeriatrics, 1-5. https://doi.org/10.1017/S1041 610220001593

Department of Health. (2012). The national carers' strategy: Recognised, supported, empowered. Department of Health.

Drabble, L., Trocki, K. F., Salcedo, B., Walker, P. C., \& Korcha, R. A. (2016). Conducting qualitative interviews by telephone: Lessons learned from a study of alcohol use among sexual minority and heterosexual women. Qualitative Social Work, 15(1), 118-133. https://doi. org/10.1177/1473325015585613

European Parliament. (2019). Directive (EU) 2019/1158 of the European Parliament and of the Council of 20 June 2019 on work-life balance for parents and carers and repealing Council Directive 2010/18/ EU. Retrieved from https://eur-lex.europa.eu/legal-content/EN/ ALL/?uri=CELLAR:4119596d-a475-11e9-9d01-01aa75ed71a1

Family Carers Ireland. (2019). Paying the price: The physical, mental and psychological impact of caring. Retrieved from https://familycarers.ie/ media/1421/paying-the-price-the-physical-mental-and-psychologi cal-impact-of-caring.pdf

Family Carers Ireland. (2020). Caring through COVID: Life in lockdown. Retrieved from https://familycarers.ie/media/1394/caring-throughcovid-life-in-lockdown.pdf

Gallagher, S., \& Wetherell, M. A. (2020). Risk of depression in family caregivers: Unintended consequence of COVID-19. BJPsych Open, 6(6). https://doi.org/10.1192/bjo.2020.99

Giebel, C., Cannon, J., Hanna, K., Butchard, S., Eley, R., Gaughan, A., Komuravelli, A., Shenton, J., Callaghan, S., \& Tetlow, H., \& Limbert, S. (2020). Impact of COVID-19 related social support service closures on people with dementia and unpaid carers: A qualitative study. Aging \& Mental Health, 1-8. https://doi.org/10.1080/13607 863.2020.1822292

Goode, W. J. (1960). A theory of role strain. American Sociological Review, 25, 483-496. https://doi.org/10.2307/2092933

Greenhaus, J. H., \& Beutell, N. J. (1985). Sources and conflict between work and family roles. The Academy of Management Review, 10(1), 7688. https://doi.org/10.2307/258214

Health Service Executive (HSE). (2020). Covid-19 home working guideline document. Retrieved from https://www.hse.ie/eng/staff/safetywell being/healthsafetyand\%20wellbeing/health-and-safety-guidelineto-home-working-during-covid-19.pdf

Hobfoll, S. E. (1989). Conservation of resources: A new attempt at conceptualizing stress. American Psychologist, 44(3), 513-524. https:// doi.org/10.1037/0003-066X.44.3.513

Hobfoll, S. E. (2001). The influence of culture, community, and the nested-self in the stress process: Advancing conservation of resources theory. Applied Psychology, 50(3), 337-421. https://doi. org/10.1111/1464-0597.00062

Ireson, R., Sethi, B., \& Williams, A. (2018). Availability of caregiverfriendly workplace policies (CFWP s): An international scoping review. Health \& Social Care in the Community, 26(1), e1-e14. https://doi. org/10.1111/hsc.12347

Johns Hopkins University of Medicine. (2020, October 30). Coronavirus Resource Centre. Retrieved from https://coronavirus.jhu.edu/

Joseph, G., \& Joseph, A. (2019). Exploring employment as a space of respite and resistance for family caregivers. Health \& Social Care in the Community, 27(6), 1481-1489. https://doi.org/10.1111/hsc.12819

Kahn, R. L., Wolfe, D. M., Quinn, R. P., Snoek, J. D., \& Rosenthal, R. A. (1964). Organizational stress: Studies in role conflict and ambiguity. Wiley.

Keating, N., \& Eales, J. (2017). Social consequences of family care of adults: A scoping review. International Journal of Care and Caring, 1(2), 153-173. https://doi.org/10.1332/239788217X14937990731749 
Kmietowicz, Z. (2020). Clinically extremely vulnerable adults should not leave home for work, says new advice. British Medical Journal, 371. https://doi.org/10.1136/bmj.m4292

Lafferty, A., Dowling-Hetherington, L., Fahy, M., Paul, G., Phillips, D., Fealy, G., Maloney, B., Duffy, C., \& Kroll, T. (2020). Submission to the public consultation on flexible working department of justice and equality. Retrieved from https://carewellproject.files.wordpress.com/2020/02/publicconsultation-on-flexible-working_final_31jan2020_carewellucd.pdf

Lazarus, R. S., \& Folkman, S. (1984). Stress, appraisal, and coping. Springer.

Lightfoot, E., \& Moone, R. P. (2020). Caregiving in times of uncertainty: Helping adult children of aging parents find support during the COVID-19 Outbreak. Journal of Gerontological Social Work. https:// doi.org/10.1080/01634372.2020.1769793

Maynard, K., llagan, C., Sethi, B., \& Williams, A. (2018). Gender-based analysis of working-carer men: A North American scoping review. International Journal of Care and Caring, 2(1), 27-48. https://doi. org/10.1332/239788218X15187914567891

Morse, J. M. (2015). Data were saturated. Qualitative Health Research, 25(5), 587-588. https://doi.org/10.1177/1049732315576699

Newell, R., \& Burnard, P. (2010). Research for evidence-based practice in healthcare. John Wiley \& Sons.

Pakpour, A. H., \& Griffiths, M. D. (2020). The fear of COVID-19 and its role in preventive behaviors. Journal of Concurrent Disorders. Retrieved from https://concurrentdisorders.ca/2020/04/03/thefear-of-covid-19-and-its-role-in-preventive-behaviors/

Pearlin, L. I., Mullan, J. T., Semple, S. J., \& Skaff, M. M. (1990). Caregiving and the stress process: An overview of concepts and their measures. The Gerontologist, 30(5), 583-594. https://doi.org/10.1093/geront/30.5.583

Phillips, D., Paul, G., Fahy, M., Dowling-Hetherington, L., Kroll, T., Moloney, B., Duffy, C., Fealy, G., \& Lafferty, A. (2020). The invisible workforce during the COVID-19 pandemic: Family carers at the frontline [version 1; peer review: 2 approved]. HRB Open Research, 3(24), 24. https://doi.org/10.12688/hrbopenres.13059.1

Pickard, L., Brimblecombe, N., King, D., \& Knapp, M. (2018). 'Replacement Care' for working carers? A longitudinal study in England, 201315. Social Policy \& Administration, 52(3), 690-709. https://doi. org/10.1111/spol.12345

Power, K. (2020). The COVID-19 pandemic has increased the care burden of women and families. Sustainability: Science, Practice and Policy, 16(1), 67-73. https://doi.org/10.1080/15487733.2020.1776561
Redmond, P., \& McGuinness, S. (2020). Who can work from home in Ireland? ESRI Survey and statistical report series number 87 May 2020. https://doi.org/10.26504/sustat87

Stokes, J. E., \& Patterson, S. E. (2020). Intergenerational relationships, family caregiving policy, and COVID-19 in the United States. Journal of Aging \& Social Policy, 1-9. https://doi.org/10.1080/08959 420.2020.1770031

Tamiolaki, A., \& Kalaitzaki, A. E. (2020). That which does not kill us, makes us stronger: COVID-19 and posttraumatic growth. Psychiatry Research. https://doi.org/10.1016/j.psychres.2020.113044

Van Houtven, C. H., DePasquale, N., \& Coe, N. B. (2020). Essential long-term care workers commonly hold second jobs and double-or triple-duty caregiving roles. Journal of the American Geriatrics Society. https://doi.org/10.1111/jgs.16509

Wilensky, H. L. (1960). Work, careers and social integration. International Social Science Journal, 12(4), 543-560.

Willner, P., Rose, J., Stenfert Kroese, B., Murphy, G. H., Langdon, P. E., Clifford, C., Hutchings, H., Watkins, A., Hiles, S., \& Cooper, V. (2020). Effect of the COVID-19 pandemic on the mental health of carers of people with intellectual disabilities. Journal of Applied Research in Intellectual Disabilities, 33(6), 1523-1533. https://doi.org/10.1111/jar.12811

World Health Organization. (2020, October 30). Coronavirus. Retrieved from https://www.who.int/health-topics/coronavirus\#tab=tab_1

Yeandle, S. (2017). Work-care reconciliation policy: Legislation in policy context in eight countries. Retrieved from http://circle.group.shef.ac.uk/ wp-content/uploads/2018/11/yeandle-WCR-v2.pdf

Zamani, G. H., Gorgievski-Duijvesteijn, M. J., \& Zarafshani, K. (2006). Coping with drought: Towards a multilevel understanding based on conservation of resources theory. Human Ecology, 34(5), 677-692. https://doi.org/10.1007/s10745-006-9034-0

How to cite this article: Lafferty A, Phillips D, DowlingHetherington L, et al. Colliding worlds: Family carers' experiences of balancing work and care in Ireland during the COVID-19 pandemic. Health Soc Care Community. 2021;00:110. https://doi.org/10.1111/hsc.13365 